\title{
POSTER EDUKASI DAN PENDAMPINGAN PEMBELAJARAN PADA ERA NEW NORMAL DI TAMAN PENDIDIKAN AL-QUR'AN
}

\author{
Eko Setiawan*, Lia Miftakhul Jannah, Rahmawati, Sofiatul Mukaromah, \\ Devi Pujiyanti, Anissa Zelitha \\ Fakultas Agama Islam, Universitas Islam Malang \\ *korespondensi email: ekosetiawan@unisma.ac.id
}

\begin{abstract}
ABSTRAK
Salah satu upaya yang dapat dilakukan untuk menjaga pola hidup bersih dan sehat dengan melakukan sosialisasi melalui poster edukasi. Perilaku hidup bersih dan sehat sangat penting pada era new normal. Pada kenyataanya, masih banyak yang belum mengetahui pentingnya pola hidup bersih dan sehat. Oleh karena itu dilakukannya program KSM-Tematik Unisma sosialisasi dan edukasi tentang perilaku pola hidup bersih dan sehat di TPQ Salafiyah desa Klampok. Tujuannya agar masyarakat khususnya anak-anak mengerti dan paham akan pentingnya menjaga kesehatan sebagai upaya pemutusan rantai penyebaran Covid-19. Selain itu adanya kegiatan pendampingan pembelajaran Al-Qur'an yang bertujuan untuk mengatasi kesulitan belajar serta memahami dan menerapkan kaidah ilmu Tajwid sehingga dapat membaca Al-Qur'an dengan baik dan benar. Program kegiatan ini dilaksanakan 1 bulan penuh meliputi observasi, analisis masalah, pembuatan sarana yang dibutuhkan untuk sosialisasi. Adapun teknis pelaksanaanya dengan partisipasi langsung ke lembaga TPQ dengan sambutuan yang ramah antusias dan semangat sehingga kegiatan dapat terlaksana dengan lancar. Hasil dari kegiatan pendampingan yang dilakukan oleh mahasiswa KSM Unisma menjadikan para santri lebih memahami dan mengerti kaidah tajwid dalam membaca Al-Qur'an.
\end{abstract}

Kata Kunci: sosialisasi; poster edukasi; pendampingan pembelajaran

\section{PENDAHULUAN}

Peran penting pendidikan dalam menciptakan kehidupan masyarakat yang berwawasan luas, cerdas, tanggap, berakhlak baik dan berjiwa demokratis perlu diwujudkan dengan tetap memegang teguh nilai-nilai ketimuran. Oleh karena itu, upaya untuk memajukan pendidikan sangat perlu dukungan dan bantuan dari berbagai pihak tak terkecuali pemerintah. Maju mundurnya negara, tergantung dari rendah tingginya kualitas Pendidikan (Puspitasari \& Hidayatullah, 2020; Widiansyah, 2017). Berdasarkan Undangundang Nomor 20 Tahun 2003, tedapat 3 jalur pendidikan, yakni pendidikan formal, nonformal, dan informal. Proses pendidikan seharusnya tidak hanya berpusat di sekolah saja atau hanya pendidikan formal melainkan proses pendidikan nonformal dan informal juga dapat diikuti untuk menunjang pengetahuan dan keterampilannya (Dinasari et al., 2018; Ernawati \& Mulyono, 2017).

Pendidikan nonformal diselenggarakan bagi masyarakat yang membutuhkan layanan pendidikan yang berfungsi sebagai penambah, pengganti, atau pelengkap pendidikan formal. Sedangkan untuk pendidikan informal dapat dilakukan melalui keluarga dan 
lingkungan dalam suatu kegiatan, seperti kelompok belajar, majlis taklim, atau lembaga pelatihan lainnya yang dapat dengan mudah diselenggarakan oleh masyarakat untuk mengembangkan ilmu pengetahuan dan kecakapan hidup.

Pada akhir Desember 2019 di kota Wuhan, Cina ditemukan kasus pertama yakni penyakit SARS-CoV-2 yang sering disebut virus Corona atau Covid-19 yang menular antar manusia dengan sangat cepat dan menyebar ke puluhan negara, termasuk Indonesia, hanya dengan waktu beberapa bulan saja (Safi et al., 2021). Dengan adanya Covid-19 memberikan dampak dari berbagai sektor mulai dari perekonomian, pariwisata, dan pendidikan. Dari sektor pendidikan semua kegiatan pembelajaran di sekolah harus dilakukan di rumah.

Saat ini Indonesia telah memasuki era tatanan baru atau yang biasa disebut Era New Normal sejak bulan Juli 2020. Hal yang membedakan antara masa pandemi dengan new normal adalah kondisi ini tidak seperti sebelum terjadi masa pandemi Covid-19, namun dengan segala sesuatunya sangat dibatasi sesuai dengan protokol kesehatan pencegahan Covid-19. Berbagai bentuk upaya dilakukan oleh lembaga pendidikan formal ataupun nonformal untuk melindungi setiap masyarakat terpapar Covid-19 agar proses pembelajaran tetap berjalan walaupun dengan adanya batasan.

Pengabdian kepada masayarakat merupakan salah satu komponen aktivitas akademik yang merupakan bagian dari Tri Dharma Perguruan Tinggi, disamping pendidikan dan penelitian (Dzurrahmi et al., 2021). Dengan diadakannya Dharma pengabdian masyarakat diharapkan dapat terjadi interelesasi antara oerguruan tinggi dan masyarakat. pengabdian masyarakat dapat diwujudkan dalam bentuk pendampingan pembelajaran AlQur'an di TPQ. TPQ merupakan instrumen pemberdayaan untuk anak yang memiliki peranan strategis dalam meningkatkan kualitas masyarakat yang berakhlak maupun berwawasasan Qur'ani.

Pengabdian masyarakat diwujudkan dengan berpartisipasi melakukan pendampingan pembelajaran yang dilakukan oleh mahasiswa KSM-Tematik Unisma di TPQ Salafiyah tepatnya di Desa Klampok Kecamatan Singosari Kabupaten Malang. Pendampingan yang dilakukan adalah dengan ikut mengajar disertai dengan edukasi tentang pentingnya menjaga pola hidup bersih dan sehat sebagai salah satu upaya pencegahan penyebaran Covid-19. Pembelajaran di TPQ Salafiyah dengan menggunakan metode Qiroati yang merupakan suatu model belajar Al-Qur'an yang secara langsung tanpa dieja dengan disertai pembiasaan membaca secara tartil sesuai kaidah tajwid.

Membaca Al-Qur'an secara langsung tanpa dieja, maksudnya adalah huruf yang ditulis dalam bahasa arab dibaca secara langsung tanpa diuraikan cara melafalkannya (Mustamin et al., 2020). Target utama dari metode Qiroati agar anak-anak dapat secara langsung mempraktekkan bacaan-bacaan Al-Qur'an secara baik dan benar sesuai dengan kaidah tajwid. Ukuran standar kemampuan anak-anak, yaitu mampu membaca Al-Qur'an dengan lancar dan benar. Sistem dari metode Qiroati bahwa lama masa belajar tidak ditentukan ataupun ditargetkan, melainkan tergantung dari kemauan, semangat, dan kepatuhan dalam belajar.

Berdasarkan hasil pengamatan di lapangan, yaitu di Desa Klampok menujukkan bahwa masih terdapat guru yang masih belum mencapai target, alokasi waktu untuk mendampingi anak-anak belajar masih sangat kurang, keterampilan orang tua dalam menjelasakan kepada anaknya kurang kreatif dan inivatif, dan masih banyak ditemukan anak-anak yang tidak mematuhi protokol kesehatan. Oleh karena itu, mahasiswwa KSMTematik Unisma tertarik untuk melakukan pendampingan pembelajaran di TPQ Salafiyah Desa Klampok. 


\section{METODE}

Program ini dijalankan selama 1 bulan oleh mahasiswa KSM-Tematik Berbasis Keilmuan dan Domisili Edisi Covid-19 Universitas Islam Malang dengan melakukan pendampingan pembalajaran di TPQ Assalafiyah Desa Klampok, Kecamatan Singosari, kabupaten Malang pada 30 Januari s/d 2 Maret 2021. Program ini mendukung peningkatan kualitas pendidikan anak-anak dengan adanya pendampingan dan pelatihan untuk melatih mental dan karakter anak-anak. Bentuk kegiatan yang dilakukan adalah mengajar atau KBM di TPQ Assalafiyah dan edukasi mengenai pola hidup bersih dan sehat melalui kegiatan mengajak untuk selalu menggunakan masker, cuci tangan dan menjaga jarak.

Penelitian ini menggunakan metode parsitipatif dengan pendekatan deskriptif kualitatif, karena data yang diperoleh berdasarkan penyajian yang sebenarnya sesuai dengan kondisi di lapangan. Menurut Bogdan dan Taylor dalam Lexy Moleong (Kusnadi et al., 2018) menyatakan, bahwa metodologi penelitian kualitatif sebagai prosedur penelitian yang menghasilkan data deskriptif, berupa kata-kata tertulis atau lisan dari perilaku orang-orang yang bisa diamati. Peneliti kualitatif dalam memulai kerjanya dengan memahami gejalagejala yang menjadi pusat perhatiannya. Dengan jalan terjun secara langsung atau bisa disebut participant observation ke dalam lapangan dengan pikiran seterbuka mungkin, serta membiarkan inpresi timbul.

Lokasi penelitian ini dilaksanakan di TPQ Salafiyah Desa Klampok Singosari Malang dengan objek penelitian menggunakan santri-santri TPQ Salafiyah. Program-program yang telah dibuat kemudian dijalankan untuk dapat dilakukan evaluasi ketercapaian program. Jenis data yang digunakan dalam penelitian ini adalah data primer. Data primer diperoleh dari informan secara langsung dari pihak yang berperan penting di desa tempat penelitian. Teknik pengumpulan data yang telah dilaksanakan kemudian dianalisis dan dibuat kesimpulan bahwa program yang telah dijalankan dapat ditindaklanjuti oleh masayarakat di Desa Klampok.

Kegiatan pendampingan pembelajaran di TPQ dilakukan dengan tetap memperhatikan dan menjalankan protokol kesehatan. Hal-hal yang dilakukan diantaranya mencuci tangan, memakai hand sanitizer, menggunakan masker dan jaga jarak. Dengan adanya pendampingan yang dilakukan untuk meningkatkan motivasi belajar pada siswa

\section{HASIL DAN PEMBAHASAN}

Program Pengabdian Masyarakat ini dibuat untuk memberikan pendampingan dalam pembelajaran Al-Qur'an sebagai upaya meningkatkan antusias, kemauan anak-anak dalam belajar membaca Al-Qur'an dan meningkatkan pengetahuan pendidikan agama Islam di desa Klampok. kegiatan pendampingan ini diawali dengan edukasi mengenai pentingnya menjaga pola hidup bersih dan sehat, serta pencegahan penyebaran Covid-19. Selain itu para santri diberi motivasi untuk mempelajari Al-Qur'an dengan baik dan benar dan manfaat apa yang didapat dari belajar Al-Qur'an. Pelaksanaan kegiatan pendampingan pembelajaran di TPQ Salafiyah terdiri dari beberapa tahap, yaitu sebagai berikut:

\section{Edukasi Pola Hidup Bersih dan Sehat}

Pada tahap pertama pengabdian masyarakat yang dilakukan mahasiswa KSM Unisma adalah melakukan edukasi mengenai menjaga pola hidup bersih dan sehat dengan menggunakan metode ceramah. Materi edukasi yang disampaikan oleh mahasiswa KSM Unisma meliputi cara menjaga kebersihan lingkungan, banyak mengkonsumsi makanan seperti sayur dan buah, banyak meminum air putih, dan berolahraga secukupnya. Kemudian para santri diberikan kesempatan untuk bertanya mengenai materi edukasi yang telah disampaikan. Hal ini bertujuan untuk mengajarkan 
para santri untuk tetap menjaga pola hidup bersih dan sehat di era new normal ini sebagai bentuk langkah pencegahan Covid-19.

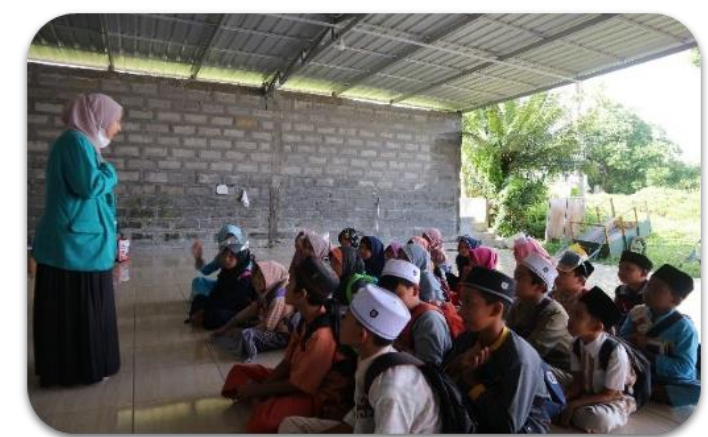

Gambar 1. Edukasi mengenai pola hidup bersih dan sehat

\section{Poster Edukasi Pencegahan Covid-19}

Pada tahap kedua kegiatan yang dilakukan pembuatan poster edukasi sebagai sarana sosialisasi bagi masyarakat yang kurang memiliki pemahaman. Poter edukasi ini berisi gambar animasi tentang tata cara menjaga kesehatan pada masa pandemic Covid19. Setelah pembuatan selesai dan sesuai dengan keadaan lingkungan disana poster di cetak dengan jumlah yang dibutuhkan. Selanjutnya mahasiswa KSM Unisma menyiapkan masker untuk dibagiakan kepada para santri pada saat sosialisasi berlangsung. Kegiatan pelaksanaan dimulai dari:

a. Memperkenalkan diri dan menyampaikan maksud dan tujuan sosialisasi yang dilakukan oleh mahasiswa KSM Unisma

b. Menyampaikan sosialisasi dengan cara membagikan masker serta dilakukan penempelan poster disekitar lingkung TPQ Salafiyah.

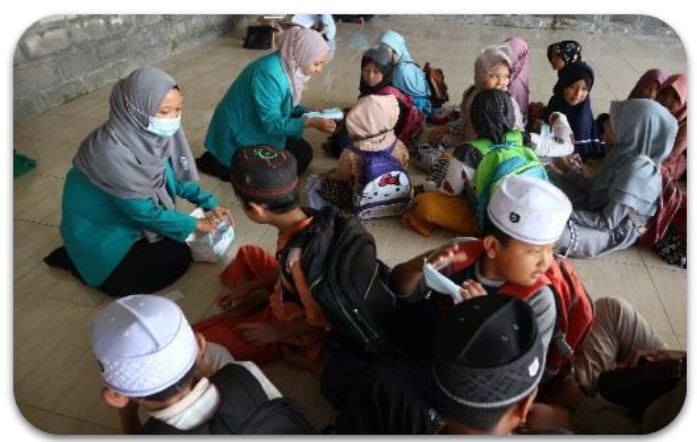

Gambar 2. Pembagian Masker pada para santri

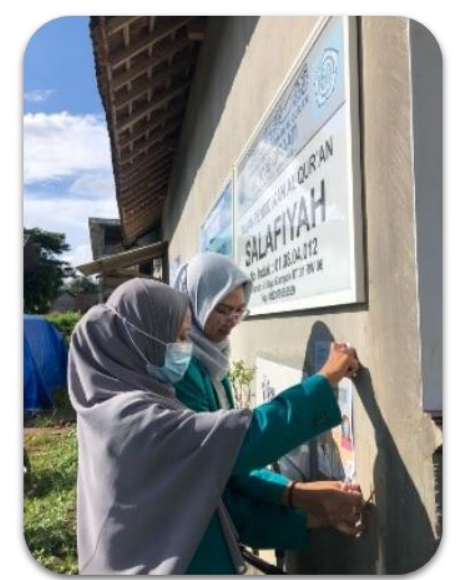

Gambar 3. Penempelan poster edukasi 
Menurut Indrawatiningsih \& Mutmainah (2020) Penyuluhan atau sosialisasi kesehatan merupakan suatu kegiatan pendidikan kesehatan, yang dilakukan dengan menyebarkan pesan, menanamkan keyakinan sehingga setiap orang tidak hanya sadar melainkan tahu dan mengerti, tetapi juga mau dan dapat melakukan anjuran yang berkaitan dengan kesehatan. Poster edukasi yang telah disosialisasikan oleh mahasiswa KSM Unisma menjadikan para santri menyadari dan menerapkan akan pentingnya pencegahan Covid-19 yang dimulai dari mencuci tangan hingga menjaga daya tahan tubuh.

\section{Pendampingan Pembelajaran Al-Qur'an}

Pada tahap ketiga ini kegiatan pembelajan pendidikan agama di era new normal santri TPQ Salafiyah tidak menerapkan sistem pembelajaran daring, dikarenakan pentingnya musyafah yang merupakan metode belajar Al-Qur'an yang mensyaratkan perjumpaan secara langsung antara murid dengan guru. Pendampingan yang dilakukan oleh mahasiswa KSM Unisma dengan berpartisipasi secara langsung mengajar anakanak belajar membaca Al-Qur'an. Tidak hanya diajarkan membaca tetapi juga diajarkan bagaimana kaidah hukum tajwid. Hal ini dikarenakan sebagian banyak santri dalam membaca Al-Qur'an seringkali tidak mengetahui kaidah tajwid apa yang terdapat dalam ayat tersebut, sehingga mahasiswa KSM Unisma melakukan pendampingan pembelajaran mengenai kaidah hukum tajwid. Selain itu para santri juga diajarkan untuk menghafal surat-surat pendek dan do'a harian.

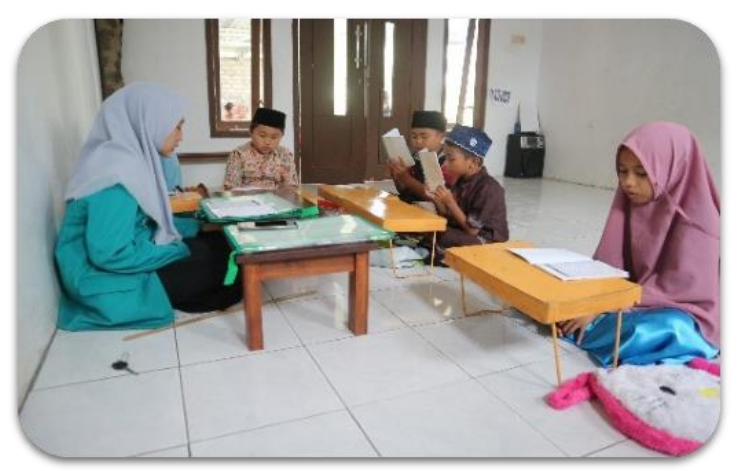

Gambar 4. Membaca Al-Qur'an dengan kaidah Tajwid

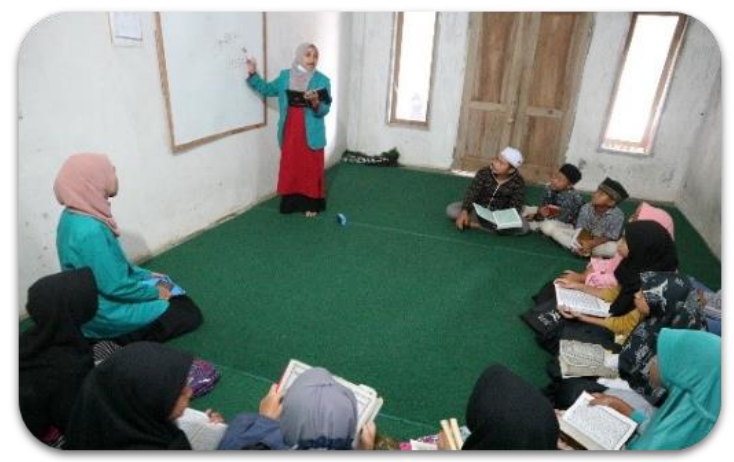

Gambar 5. Pembelajaran hukum-hukum Tajwid kaidah Tajwid

Pendampingan pembelajaran yang telah dilaksanakan oleh mahasiswa KSM Unisma diharapkan dapat memberikan pengetahuan baru bagi anak-anak untuk kemudian diterapkan dalam kehidupan sehari-hari saat membaca Al-Qur'an. Sejauh pendampingan pembelajaran dilakukan tidak ada kendala yang spesifik, semua berjalan dengan lancar dan teratur, hanya saja ada beberapa anak yang rame sehingga 
menganggu penjelasan yang disampaikan oleh mahasiswa KSM Unisma. Hasil dari kegiatan pendampingan yang dilakukan oleh mahasiswa KSM Unisma menjadikan para santri lebih memahami dan mengerti kaidah tajwid dalam membaca Al-Qur'an. Tidak hanya penyampaian melalui teori saja melainkan juga dipraktikkan dalam membaca AlQur'an sehingga para santri dapat mengidentifikasi hukum-hukum tajwid apa saja yang terdapat dalam satu ayat yang telah dibaca.

\section{KESIMPULAN}

Pengabdian masyarakat yang dilakukan dengan kegiatan edukasi dan pendampingan pembelajaran di TPQ Salafiyah desa Klampok terlaksana dengan baik sesuai dengan yang direncanakan. Dari hasil evaluasi berupa observasi dan wawancara dengan Kepala TPQ selama menjalankan kegiatan tersebut dapat disimpulkan bahwa kegiatan pengabdian masyarakat ini mendapat tanggapan positif dari masyarakat, para santri, dan juga Kepala TPQ dengan adanya kegiatan edukasi mengenai pola hidup bersih dan sehat serta pendampingan pembelajaran Al-Qur'an dapat memberikan wawasan serta dapat membantu mengatasi kesulitan dalam belajar Al-Qur'an sehingga dapat memberikan dampak positif. Selain itu poster edukasi dapat dijadikan sebagai media pesan untuk melakukan pencegahan bagi diri sendiri.

\section{UCAPAN TERIMA KASIH}

Terima kasih disampaikan kepada Bapak Kusnadi selaku Kepala Desa Klampok Singosari yang telah mendukung dan mensukseskan program keja yang kami lakukan dan seluruh pihak yang terlibat yang tidak dapat kami sebutkan satu persatu, serta pihak LPPM (Lembaga Penelitian dan Pengabdian Masyarakat) Universitas Islam Malang yang telah memberikan kesempatan untuk melaksanakan kegiatan ini.

\section{DAFTAR RUJUKAN}

Dinasari, I., Saroh, S., \& Sumartono. (2018). Pemanfaatan Potensi Lokal Lembaga Pendidikan Madrasah Sebagai Pembelajaran Usaha Produktif. Jurnal Inovasi Hasil Pengabdian Masyarakat (JIPEMAS), 1(1), 39-53. https://doi.org/10.33474/jipemas.v1i1.1478

Dzurrahmi, B. D. N., Asniwati, A., Azmi, A., Sarmadiyanti, B. N. A., Lestari, H. F., Ayunah, S. A., Ridwan, M. H., \& Zubair, M. (2021). Pendampingan Pendidikan Non-Formal di Desa Wisata Hijau Bilebante dalam Kelompok Belajar "Bale Cerdas." Jurnal Pengabdian Magister Pendidikan IPA, 4(1), 2-7. https://doi.org/10.29303/jpmpi.v4i1.606

Ernawati, \& Mulyono, S. E. (2017). Manajemen Pembelajaran Program Paket C Di Pkbm Bangkit Kota Semarang. Journal of Nonformal Education, 3(1), 60-71. https://doi.org/10.15294/jne.v3i1.8915

Indrawatiningsih, N., \& Mutmainah. (2020). Penyuluhan Perilaku Hidup Bersih dan Sehat terhadap Masyarakat Buta Huruf Masa Pandemi Covid-19 di Dusun Pacinan RT01/RW01 Desa Sedarum Kec. Nguling Kab. Pasuruan. Jurnal Abdimas, 24(1), 7-11. https://journal.unnes.ac.id/nju/index.php/abdimas/article/view/26225

Kusnadi, D., Fattah, N., Husaini, A., \& Ruhenda, R. (2018). Efektivitas Implementasi Kebijakan Penilaian Autentik pada Pembelajaran Pendidikan Agama Islam. Ta'dibuna: Jurnal Pendidikan Islam, 7(1), 20. https://doi.org/10.32832/tadibuna.v7i1.1348

Mustamin, Habiballah, A. I., \& Alex, A. (2020). Pendampingan Pembelajaran pada Era New Normal di TPQ dan Bimbingan Belajar Tingkat SD/MI di Sidodadi. JUMAT Jurnal Pengabdian Masyarakat Bidang Keagamaan, 1(1), 13-15. https://ejournal.unwaha.ac.id/index.php/abdimas_agama/article/view/1060

Puspitasari, N. A., \& Hidayatullah, S. (2020). Peningkatan wawasan penerapan model 
pembelajaran berorientasi HOTS (Higher Order Thinking Skill) bagi guru MTs dan MA. Jurnal Inovasi Hasil Pengabdian Masyarakat (JIPEMAS), 3(2), 128-135. https://doi.org/10.33474/jipemas.v3i2.6131

Safi, I., Candra, A. I., Widodo, S. R., Santoso, A., Heryanto, B., Winarti, E., \& Rahmadi, A. N. (2021). Pembuatan masker dan bilik disinfektan sebagai upaya membantu masyarakat terdampak covid-19. Jurnal Inovasi Hasil Pengabdian Masyarakat (JIPEMAS), 4(1), 36-45. https://doi.org/10.33474/jipemas.v4i1.7524

Widiansyah, A. (2017). Peran Ekonomi dalam Pendidikan dan Pendidikan dalam Pembangunan Ekonomi. Jurnal Cakrawala, 17(2), 207-215. https://doi.org/10.31294/jc.v17i2.2612 